\title{
Preface to festschrift dedicated to Prof J.J. Venter
}

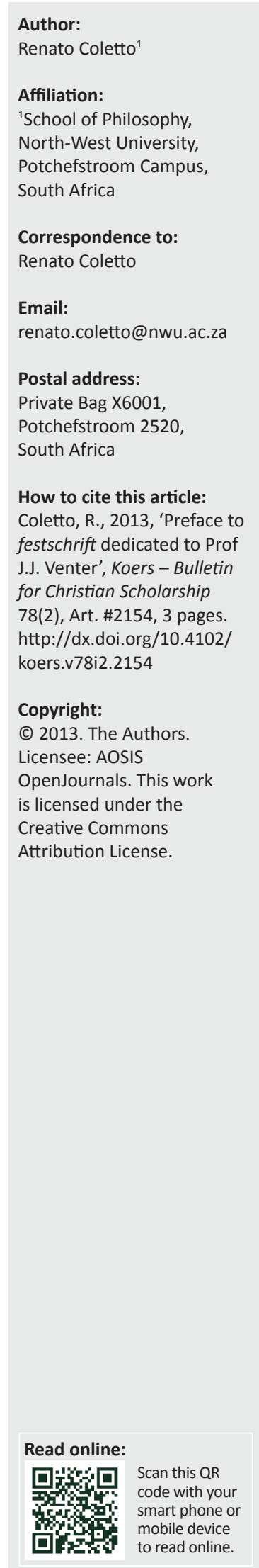

It is a pleasure and honour to be able to commemorate Professor J.J. (Ponti) Venter's life-long contribution to Christian philosophy and scholarship with this special edition of Koers - Bulletin for Christian Scholarship. It is certainly not by chance that most of the articles appearing in this issue are written by former students of 'Prof Ponti'. Those of us who had the privilege of attending his classes or of completing theses and dissertations under his supervision are still grateful for his generous support, his lenient attitude and his enthusiasm.

As students, we were often impressed by his detailed knowledge of the history of philosophy and by his infinite willingness to supply new insights. It became a custom, for example, when one was looking for a reference, to simply go to 'Prof Ponti' and ask: 'Do you perhaps remember in which dialogue Plato mentions the idea of a bed and ...' And then he would complete the sentence: '... and the idea of a hair and of dirt ... yes it should be in this book, in that section ...' The astonished student would then go and find the reference precisely in that book and section. The student would also notice that, in that passage, Plato mentions exactly a bed, hair and dirt!

Professor Venter's competence, however, was not an end in itself: It was channelled to the promotion of Christian-reformational philosophy, in the tradition of Dooyeweerd and Vollenhoven. What emerges from the present contributions, written by students and colleagues from several continents, is the moderate, nuanced position that Ponti adopted in many cases and on different topics. This might surprise some, given the fact that 'Prof Ponti' was a representative of a philosophical trend sometimes regarded as 'radical'. In addition, he often did not refrain from voicing his own concerns and opinions in rather straightforward terms! I therefore believe these articles will disclose (at least to some) a new image of 'Prof Ponti'.

This special issue also contains several articles written by Professor Venter himself. It was an idea first suggested by Professor Bennie van der Walt, who felt that there was still a lot that Ponti had not put on paper. So we left 'the last word' to Professor Venter (in the printed edition, his articles conclude the issue). The readers will appreciate his volcanic style in articles that (even after radical re-sizing) exceed by far the standard length and the standard level of emotional involvement. A crowd of reviewers (anonymous but unanimous) recognised the 'erudition' of these contributions but, concerning the style, recommended to 'tone down', to limit, to nuance. In the process, we realised that it is impossible to quench Professor Venter's style without suppressing something peculiar to his personality. So we tried to preserve as much as possible of the original 'verve', confiding in the fact that, as already mentioned, the content is always well-meditated, never onesided, always balanced.

I am sure the readers will enjoy Professor Venter's contributions and the other articles dedicated to him.

\section{Selected bibliography}

\section{Theses}

'Die waarheidsprobleem in die ontologie van die Voor-Sokratici', Master's thesis, Potchefstroom University for Christian Higher Education. (Supervised by Prof J.A.L. Taljaard)

'De taak van de universiteit' [The task of the university - published in Dutch], Mini-dissertation for Drs. Phil., Potchefstroom University for Christian Higher Education. (Supervised by Prof H. Van Riessen)

'Geloofsgebonde denke by Anselmus - 'n Studie van sy wysgerige metode' [Thinking within the bounds of faith in Anselm - A study of his philosophical method], Ph.D thesis, Potchefstroom University for Christian Higher Education. (Supervised by Prof. N.T. van der Merwe)

Inaugural address as full professor: Caritas, scientia, sapientia - filosofie en universitêre wetenskapsbeleid [Philosophy and university science policy - published in Afrikaans]

\section{Academic articles}

2009, 'Philosophical issues in environmental management: The nature-culture dialectic and "sustainability", Acta Academica 41(1), 22-68.

2007, 'Dignity and work: Global market and self-sustenance', TD: The Journal for Transdisciplinary Research in Southern Africa 3(1), 133-168. 
2006, 'A creative humane university. Coping with the business model', Koers - Bulletin for Christian Scholarship 71(2-4), 357-397.

2006, 'A human(e) uni-versity: Resisting scientism, technicism, and economism', Koers - Bulletin for Christian Scholarship 71(1), 275-318.

2004, 'Human dignity and the objectification of the human being', Analecta Husserliana 79, 545-609.

2002, "Nature", "law", "humanity": The rise of positivism: Quesnay, Turgot, Comte', Acta Academica 34(1), 1-55.

2002, 'Human dignity in weakness: Gabriel Marcel's conception of human dignity (versus Mussolini and Skinner)', Analecta Husserliana 74(1), 351-372.

2002, 'Economism: The debate about the universality claims of orthodox economics', Analecta Husserliana 76, 289-320.

2001, 'Early modern conceptions of "natural law"', Acta Academica 33(2), 1-39.

2000, 'How worldviews germinate: Genesis versus the occult worldviews', Tydskrif vir Christelike wetenskap 36(1/2), 37-76.

2000, "Human dignity" as "rationality": The development of a conception, Analecto Husserliana 68, 129-159.

1999, 'The role of philosophy in the reformational Christian university', Tydskrif vir Christelike Wetenskap 35(3/4), 163-200.

1999, 'H.F. Verwoerd: Foundational aspects of his thought', Koers - Bulletin for Christian Scholarship 64(4), 415-442.

1999, “"Modernity”: The historical ontology', Acta Academica 31(2), 18-46.

1998, 'Metodebesinning in die Proslogion van Anselmus Cantuariensis', The SA Journal of Medieval and Renaissance Studies 8(1), 1-22.

1997, 'Mechanistic individualism versus organistic totalitarianism', International Journal for Ultimate Reality and Meaning 20(1), 41-60;

1997, 'Filosofie en wetenskapsbeleid: Caritas, scientia, sapientia', Koers - Bulletin for Christian Scholarship 62(4), 447-474.

1997, 'Metodepraktyk in die 'Proslogion van Anselmus Cantuariensis', The SA Journal of Medieval and Renaissance Studies 7(1), 1-28.

1997, 'Road-signs to "creativity"', Analecta Husserliana 53, 3-27.

1996, 'Metodebesinning in die Monologion van Anselmus Cantuariensis', The SA Journa of Medieval and Renaissance Studies 6(1), 1-37.

1996, 'Conceiving conflict/competition: Gripped by a world-picture: C. Darwin, D. H. Lawrence, F.A. von Hayek', Analecta Husserliana 48, 205-248.

1996, 'World-picture, individual, society', Neohelicon 23(1), 175-200.

1995, 'Metodepraktyk in die Monologion van Anselmus Cantuariensis', The SA Journa of Medieval and Renaissance Studies 5(1), 1-47.

1994, 'A reformationally Christian university basis at work', Orientation: Internationa Circular of the PU for CHE (71/74), 260-294.

1994, 'Transforming society', Orientation: International Circular of the PU for CHE (71/74), 295-336.

1992, 'Reason, survival, progress in eighteenth century thought', Koers - Bulletin for Christian Scholarship 57(2), 189-214.

1992, 'From machine-world to God-World: World pictures and world views', Koers Bulletin for Christian Scholarship 57(2), 189-214.

1988 , 'The strategy of the bomb and the jaw: The relation between violence, ideology and negotiation', Orientation: International Circular of the Potchefstroom University (50/51), 138-146.

1988, 'Transformation of society in the Kairos Document', Orientation: Internationa Circular of the Potchefstroom University 48(March), 104-118.

1986, 'The vital importance of Christian education at all levels for the Southern African society', Orientation: International Circular of the Potchefstroom University (43),

1986, 'Resensie: B. Duvenhage, Die Afrikaanse karakter en Christelike roeping van die PU vir CHO, Die Potchefstroomse Universiteit', Koers - Bulletin for Christian Scholarship (51), 245-248.

1984,'Kernprobleme van die wetenskapsmetodologie', Koers - Bulletin for Christian Scholarship 49(1), 23-57.

1983, 'Rasionaliteit by Anselmus van Kantelberg', Humanitas (HSRC) 9(1), 1-14.

1982 , 'Het filosofie en vakfilosofie enige betekenis vir beroepsopleiding?', Koers Bulletin for Christian Scholarship 47(2), 95-110.

1978, 'Akademie en politiek', Koers - Bulletin for Christian Scholarship 43(2), 317-329.

1978, 'Die didaktiek van die wysbegeerte as universitêre vakgebied', Perspektief 17(2), 21-62.

1977, 'Die universiteit en die toekoms', Perspektief 16(2), 73-99.

1977, 'Tension in the Christian university', Koers - Bulletin for Christian Scholarship 42(4), 301-312.

1975, 'Yesterday and today: The task of the university', Koers - Bulletin for Christian Scholarship 40(4-6), 402-424.

1969, 'Die filosofis Antoine de St. Exupery', Perspektief 8(2/3), 3-45.

\section{Contributions to books and brochures}

1995, 'Ontologie, representasie en metode', in H.M. Viljoen (red.), Metodologiese implikasies van enkele representasie-opvattings vir literatuurstudie, bl. 129-228, RGN, Pretoria.
1994, Transformasie van die samelewing, Instituut vir Reformatoriese Studies, Potchefstroom.

1991, 'Retrospect', in B.J. van der Walt (ed.), Cultural diversity in Africa, pp. 243-247, Instituut vir Reformatoriese Studies, Potchefstroom.

1990, "n Filosofiese perspektief op die New Age beweging', in B.J. van der Walt (red.), Die New Age-Beweging, pp 51-75, Instituut vir Reformatoriese Studies, Potchefstroom.

1987, 'Gesag aan die Universiteit', in B.J. van der Walt (red.), Venster op die Universiteit, bl. 108-131, Instituut vir Reformatoriese Studies, Potchefstroom.

1987, 'Die universiteit: Sy wortels en sy wese', in B.J. van der Walt (red.) Venster op die Universiteit, bl. 1-15, Instituut vir Reformatoriese Studies, Potchefstroom.

1987, Samelewingsverandering in die Kairos-dokument: 'n Reformatoriese kommentaar op die Kairos-dokument, Instituut vir Reformatoriese Studies, Potchefstroom.

1984, 'Die strategie van die bom en die bek: Oor geweld, ideologie en onderhandeling,' in B.J. van der Walt (red.), Die ideologiese stryd in Suider-Afrika, bl. 86-93, Instituut vir Reformatoriese Studies, Potchefstroom.

1984, Die behoefte aan en dringende noodsaaklikheid van Christelike universitêre opleiding vir bruin en swart Suider-Afrikaners, Instituut vir Reformatoriese Studies, Potchefstroom.

1978, 'De grondslag van een (christelijke) Universiteit', in A. Th. Bruggemann-Kruijff, B. Voorsluis \& O.K. Zijlstra (reds.), De taak van de universiteit: Wijsgerige opstellen over de universiteit, bl. 164-215, Assen, Amsterdam.

1978, 'De taak van de universiteit (Wetenschap, opleiding, vorming: Universiteit en samelewing; Taak en doel van die Universiteit)', in A. Th. Bruggemann-Kruijff, B. Voorsluis \& O. K. Zijlstra (reds.), De taak van de universiteit: Wijsgerige opstellen over de universiteit, bl.38-49, Assen, Amsterdam.

1978, 'De taak van de universiteit in historisch perspectief', in A. Th. BruggemannKruijff, B. Voorsluis \& O. K. Zijlstra (reds.), De taak van de universiteit: Wijsgerige opstellen over de universiteit, bl. 5-37, Assen, Amsterdam.

\section{Popular articles}

1997, 'Die universiteit: Wie se en watse besigheid?', Woord en Daad/Word and Action 362, 9-13.

1993, 'We have had enough!', Woord en Daad/Word and Action 33(344), 3-4. 1993, 'Pressure on authorities', Woord en Daad/Word and Action 33(345), 9-10.

1992, 'Gekonkel in die donker: Die etiek van vertroulikheid', Woord en Daad/Word and Action 32(340), 4-5.

1991, 'Modern technology and the death of culture', Woord en Daad/Word and Action 31, 4-5.

1991, 'Everything!!! under control (In our violent country)', Woord en Daad/ Word and Action 31, 7-9.

1989, 'Polarisasie en gesprek', Woord en Daad/Word and Action 29, 1-3, 15.

1989, 'Moord op universiteite?', Woord en Daad/Word and Action 29, 11-13.

1988, 'The bishop of Rome among us', Woord en Daad/Word and Action 28, 1-3.

1988, 'Rubicon III', Woord en Daad/Word and Action 28, 1-2, 14.

1988, 'Universiteit en staat', Woord en Daad/Word and Action 28, 9-12.

1988 , 'n 50/50 koalisie tussen blank en swart?', Woord en Daad/Word and Action $28,2$.

1987, 'Kenneth Kaunda: 'n Portret', Woord en Daad/Word and Action 27, 13-15.

1985, 'Geslote eredienste? Kettery', Woord en Daad/Word and Action 25, 6-8.

1983, 'Die posisie van die Christenstudent aan die "swart" Universiteit', Woord en Daad/Word and Action 23, 2-3.

1969, 'Simpatiek nogtans krities', Perspektief 8(1), 83-89.

1969, 'Dialektiek en antitese', Die Besembos, PU-studentejaarblad (wenartikel vir die jaar).

\section{Translations}

All of these translations to be found at http://www.pontiventer.yolasite.com 2013, Uniale Omsendbrief, Pretoria, 3/7/41, deur komdt-genl. dr. J.F.J. van Rensburg. (A document of the Ossewabrandwag. Bilingual translation with introduction)

2013, Marx, K. \& Engels F., Namens die werkersklas bely ons ... In the name of the working class we confess ..., Vraagteken Uitgewers, Potchefstroom. (Bilingual working class we confess ..., Vraagteken Uitgewers,
translation with introduction and marginal remarks)

2013, Comte, A., Oor taal. (Translated to Afrikaans from: Système de politique positive [Bande II en III; 1851-54], Text selected in French by Jean-Marie Tremblay, http:// www.uqac.uquebec.ca/zone30/Classiques_des_sciences_sociales/index.html)

2012, Anselmus, Proslogion. (Logically explained translation in Afrikaans)

2012, Mussolini, B \& Gentile, G., 'Ek is altyd reg' sê Broeder Leier; Skuus: Koningin By (geslagsgelykheid). (Translation into Afrikaans with bilingual commentary. Plus the earliest translation into English of the Mussolini essay, from Mussolini, B. 1928, La dottrina del fascismo [http://litgloss.buffalo.edu/mussolini/text.shtml])

2011, Van willehond tot mens: Menslike vooruitgang as wêreldnatuurgeskiedenis, drie essays, Vraagteken Uitgewers, Potchefstroom. [Translation from German into Afrikaans with philosophical introduction and annotations, from Kant, I., Idee zu einer allgemeine Geschicte in Weltbürgerliche Absicht; Beantwortung der Frage: Was ist Aufklärung; Mutmasslicher Anfang der Menschengeschicte, in Kant, Werke 
in Zehn Bänden, W. Weischedel (Hrsg.), Band 9, pp 33-50; 51-61; 83-102, WBG, Dramstadt.

2011, Meetkunde en ervaring/ Geometry and experience, Vraagteken Uitgewers, Potchefstroom. [Translation from German into Afrikaans and English, with bilingual introduction and bilingual explanation of Einstein's technical terms. (see Einstein, A., 1921, Geometrie und Erfaharung. Erweiterte Fassung des Festvortrages gehalten an der Preussischen Akademie der Wissenschaften zu Berlin am 27 January 1921 Springer, Berlin)

\section{Monographs}

2012, Responsible scholarship, Vraagteken Uitgewers, Potchefstroom

2011, Die natuur as persoon-god; die mens as ding-god; die wet as omni-god: Kopstaan humanisme van fisiokrasie tot positiwisme, Vraagteken Uitgewers, Potchefstroom.

2011, Ontmoet ' $n$ personae genaamd 'Natuur': Vroeg-moderne konsepsies van die natuurwet. Natuurlik: Alte BO-natuurlik, Vraagteken Uitgewers, Potchefstroom. 